Article (refereed) - postprint

Hayes, Felicity; Mills, Gina; Alonso, Rocio; González-Fernández, Ignacio; Coyle, Mhairi; Grünhage, Ludger; Gerosa, Giacomo; Karlsson, Per Erik; Marzuoli, Riccardo. 2019. A site-specific analysis of the implications of a changing ozone profile and climate for stomatal ozone fluxes in Europe. Water, Air, and Soil Pollution, 230 (1), 4. 15, pp. https://doi.org/10.1007/s11270-018-4057-x

(C) Springer Nature Switzerland AG 2018

This version available http://nora.nerc.ac.uk/id/eprint/522258/

NERC has developed NORA to enable users to access research outputs wholly or partially funded by NERC. Copyright and other rights for material on this site are retained by the rights owners. Users should read the terms and conditions of use of this material at http://nora.nerc.ac.uk/policies.html\#access

This document is the author's final manuscript version of the journal article following the peer review process. Some differences between this and the publisher's version may remain. You are advised to consult the publisher's version if you wish to cite from this article.

https://link.springer.com/

Contact CEH NORA team at noraceh@ceh.ac.uk

The NERC and CEH trademarks and logos ('the Trademarks') are registered trademarks of NERC in the UK and other countries, and may not be used without the prior written consent of the Trademark owner. 


\title{
A site-specific analysis of the implications of a changing ozone profile and climate for stomatal ozone fluxes in Europe
}

\author{
${ }^{1 *}$ Felicity Hayes, ${ }^{1}$ Gina Mills, ${ }^{2}$ Rocio Alonso, ${ }^{2}$ Ignacio González-Fernández, ${ }^{3}$ Mhairi Coyle, \\ ${ }^{4}$ Ludger Grünhage, ${ }^{5}$ Giacomo Gerosa, ${ }^{6}$ Per Erik Karlsson, ${ }^{5}$ Riccardo Marzuoli \\ ${ }^{1}$ Centre for Ecology and Hydrology, Deiniol Road, Bangor, Gwynedd, LL57 2UW, UK \\ ${ }^{2}$ Ecotoxicology of Air Pollution, CIEMAT. Avda. Complutense 40. 28040, Madrid, Spain \\ ${ }^{3}$ Centre for Ecology and Hydrology, Bush Estate, Penicuik, Midlothian, EH26 0QB, UK \\ ${ }^{4}$ Department of Plant Ecology, Justus-Liebig-Iniversity Giessen, Heinrich-Buff-Ring 26, D- \\ 35392 Giessen, Germany \\ ${ }^{5}$ Department of Mathematics and Physics, Catholic University of Brescia, via Musei 41, \\ 25121 Brescia, Italy \\ ${ }^{6}$ IVL Swedish Environmental Research Institute, Box 530 21, SE-400 14 Gothenburg \\ *Corresponding author.fhay@ceh.ac.uk
}

\begin{abstract}
In this study we used eight sites from across Europe to investigate the implications of a future climate $\left(2^{\circ} \mathrm{C}\right.$ warmer and $20 \%$ drier) and a changing ozone profile (increased background concentrations and reduced peaks) on stomatal ozone fluxes of three widely occurring plant species. A changing ozone profile with small increases in background ozone concentrations over the course of a growing season could have significant impacts on the annual accumulated stomatal ozone uptake, even if peak concentrations of ozone are reduced. Predicted increases in stomatal ozone uptake showed a strong relationship with latitude, and were larger at sites from northern and mid-Europe than those from southern Europe. At the sites from central and northern regions of Europe, including the UK and Sweden, climatic conditions were highly conducive to stomatal ozone uptake by vegetation during the summer months and therefore an increase in daily mean ozone concentration of $3-16 \%$ during this time of year (from increased background concentrations, reduced peaks) would have a large impact on stomatal ozone uptake. In contrast, during spring and autumn, the climatic conditions can limit ozone uptake for many species. Although small increases in ozone concentration during these seasons could cause a modest increase in ozone uptake, for those species that are active at low temperatures, a $2^{\circ} \mathrm{C}$ increase in temperature would increase stomatal ozone uptake even in the absence of further increases in ozone concentration. Predicted changes in climate could alter ozone uptake even with no change in ozone profile. For some southern regions of Europe, where temperatures are close to or above optimum for stomatal opening, an increase in temperature of $2^{\circ} \mathrm{C}$ could limit stomatal ozone uptake by enhancing stomatal closure during the summer months, whereas during the spring, when many plants are actively growing, a small increase in temperature would increase stomatal ozone uptake.
\end{abstract}

\section{Keywords}

Stomata; climate change; ozone flux; Betula pendula; Dactylis glomerata; Leontodon hispidus 


\section{Acknowledgements}

51 FH and GM would like to thank the Natural Environment Research Council (NERC) for 52 supporting this project (NEC05574). The contribution by PEK was made possible by the 53 research programme SCAC, funded by the Swedish Environmental Protection Agency. The 54 contribution of IGF and RA was funded the Spanish projects AGRISOST-CM (S2013/ABI55 2717, Comunidad de Madrid). 


\section{Introduction}

Tropospheric ozone concentrations have approximately doubled across northern mid-latitudes between 1950 and 2000 (Parrish et al., 2012). More recently, there has been a reduction in emissions of ozone precursors in Europe due to a combination of legislation and modernisation of industrial sources, which has resulted in a slowed increase in ozone concentrations at some sites e.g. rural monitoring stations in the Western Mediterranean basin (Sicard et al., 2013). European annual mean surface ozone concentrations are predicted to decrease slightly based on the Representative Concentration Pathway (RCP) greenhouse gas concentration trajectory scenarios RCP 2.6, 4.5 and 6.0, but are expected to continue to rise with the RCP 8.5 scenario (Fiore et al., 2012, Wild et al., 2012). However, these annual mean projections do not show the detail of the anticipated change in the ozone concentration profiles. In particular, whilst large episodic peaks of ozone have reduced in frequency and severity across much of Europe, low- and medium-range ozone concentrations have continued to rise over the period 1990 to 2010 in Europe and the USA (Paoletti et al., 2014; Lefohn et al., 2017; Karlsson et al., 2017). This has been attributed to factors including changing meteorological conditions, background ozone and source patterns that are not always fully incorporated into models of future ozone scenarios (Akritidis et al., 2014). Further rises in mean ozone concentration in northern Europe are predicted as it is thought that reductions in precursor emissions in this region will be outweighed by increased hemispheric transport of precursors, together with reduced titration of ozone with nitric oxide (Lacressonniere et al., 2014; Wilson et al., 2012; Lefohn et al., 2017; Karlsson et al., 2017).

Current and projected future ozone concentrations are a concern for vegetation (Royal Society, 2008; Mills et al., 2011a) and detrimental effects have been reported at ambient concentrations including for trees (Braun et al., 2014; Wittig et al., 2009) and (semi-)natural vegetation (Mills et al., 2011a). Much work on effects on vegetation has focussed on the impacts of peak ozone concentrations and therefore ozone delivery within experiments has often used a pronounced diurnal profile (e.g. Calvo et al., 2007, Bender et al., 2006). Despite the continued increase in background ozone concentrations due to the predicted changes in ozone exposure profile over the coming decades, the consequence of this for vegetation remains poorly understood (Coyle et al., 2003). Some studies, however, have shown that an increase in background ozone concentration can be as deleterious to plant health as an increase in peak concentrations (Oksanen and Holopainen, 2001; Hayes et al., 2010, Harmens et al., 2018).

Ozone enters plants through stomata, which are open when climatic conditions are favourable for gas exchange. Stomatal ozone uptake can be as high in central and northern Europe, when concentrations are moderate and climatic conditions are conducive to stomatal opening, as in more southern areas where ozone concentrations are higher but conditions for uptake are less favourable (Mills et al., 2011a). Therefore, when quantifying the risk to vegetation of ozone pollution it is important to consider ozone uptake through the stomata as this has been shown to be better related to plant effects such as crop yield loss and reduced tree growth than to concentration based metrics (e.g. Pleijel et al., 2004; Mills et al., 2011a; Büker et al., 2015). Plants have some capacity to detoxify ozone that enters leaves through the stomata, with increased damage occurring when this is exceeded (Burkey et al., 2006). Using a constant threshold for stomatal ozone flux (' $Y$ ' in PODY (Phytotoxic Ozone Dose over a threshold flux of $\mathrm{Y} \mathrm{nmol} \mathrm{m}^{-2} \mathrm{PLA} \mathrm{s}^{-1}$ ) is considered to act as a surrogate for an ozone detoxification threshold (Musselman et al., 2006) with different values used for different species (Mills et al., 2011b). Although this principal is sound for quantifying ozone impacts on individual plant species, there are mathematical implications when modelling fluxes close 
to this threshold as very small variations in value can have a large cumulative impact on PODy depending on whether or not the threshold has been reached.

A spring peak of ozone concentrations has been observed at many remote northern hemisphere sites. In northern Arizona this peak occurs in May and has been attributed to transport of precursor molecules from other regions (Diem, 2004). Over recent years there is some evidence of a change in seasonality of ozone, with peak concentrations occurring earlier in the year (Parrish et al., 2013), including in regions such as the north-eastern US as NOx emissions are reduced (Clifton et al., 2014). Furthermore, the start of spring has also been occurring increasingly earlier in some parts of Europe over recent decades (Peñuelas et al., 2002; Menzel et al., 2006), meaning that the timing of peak ozone concentrations now overlaps with early season plant growth (Karlsson et al., 2007, Karlsson et al., 2009, Klingberg et al., 2009). At this time, many species may be sensitive to ozone as they are fully metabolically active (Alonso et al., 2001), indicating that it is important to consider ozone concentrations and fluxes in spring. In some locations, an increased autumn ozone peak has also been observed, including Hong Kong (Lee et al., 2009) and the consequences of this for vegetation have not yet been investigated.

Alongside any changes in ozone concentration in future decades, there are likely to be changes in meteorological conditions, due to projected changes in climate. Although there is much variation in predictions of future climate, mean surface temperatures are likely to increase by at least $2^{\circ} \mathrm{C}$ by 2100 according to all but the most stringent mitigation scenario RCP2.6 (IPCC, 2014). Similarly, there is a spatially varying range in predictions of precipitation, however, for much of Europe a reduction in annual precipitation of $10-20 \%$ by 2100 is likely (IPCC, 2014). Both temperature and precipitation (via effects on soil moisture) affect stomatal ozone fluxes and are thus critical in determining the instantaneous and cumulative ozone uptake by plants (Klingberg et al., 2011).

In this study we investigate the possible consequences for vegetation of a combination of reduced peak and increased background ozone concentrations based on effects mediated by stomatal ozone flux for selected example sites in Europe. We use the $\mathrm{DO}_{3} \mathrm{SE}$ model (Emberson et al., 2000a, b) which uses a multiplicative algorithm, based on that developed by Jarvis (Jarvis, 1976) to estimate leaf stomatal conductance. We use 2010 as the baseline year for climate and ozone, a typical year with relatively few ozone 'episodes' and with similar exceedances of the thresholds set to protect human health as in the previous three years (EEA, 2011). We then consider the implications of a changing ozone concentration profile by calculating stomatal ozone uptake using the $\mathrm{DO}_{3} \mathrm{SE}$ model for a grass, a forb and a deciduous tree species widely found across much of Europe, using site-specific hourly ozone and climate data. Lastly, we calculate the ozone dose under current (2010) and future (2100) climatic conditions representative of RCP scenarios at the same sites to evaluate changes in potential risk to vegetation and test the hypothesis that predicted changes to climate will result in increased stomatal ozone uptake.

\section{Methods}

Stomatal ozone fluxes $\left(\mathrm{POD}_{0}\right)$ were calculated using the multiplicative model $\mathrm{DO}_{3} \mathrm{SE}$ (Emberson et al., 2000a) for three species that are commonly occurring across Europe, although they may not be part of the dominant vegetation community at all of the sites used. The model was parameterised for the species Dactylis glomerata and Leontodon hispidus using stomatal conductance measurements made using a porometer (AP4, Delta-T, UK) 
during ozone exposure experiments in solardomes at CEH Bangor, UK. In addition, the parameterisation for Betula pendula used within the UNECE was also included (LRTAP Convention, 2017), using the northern Europe parameterisation. As regional-specific parameterisations were not available for all regions of Europe, the same parameterisation was used at all sites for this simulation exercise to facilitate comparison. Further details about these experiments, the method of parameterisation and the parameterisations used are included in the supplementary material (S1). The phenology function ( $f_{\text {Phen }}$ ) was considered to be 1 at all times to avoid the potential, but currently unquantifiable, changes in plant phenology that may occur in future scenarios due to the influence of climatic changes. The stomatal response to ozone, fo3, was not included in the model as this is not yet parameterised in LRTAP Convention (2017) for trees and grassland species. For the purposes of this modelling study, no threshold was used for the accumulation of ozone fluxes to avoid having varying species-specific influences of the threshold when assessing potential differences in calculated stomatal ozone uptake, and because small differences in ozone fluxes may appear to have a disproportionately large effect if the change moves the hourly flux across the threshold. However, due to the dependence of ozone fluxes on meteorological conditions in addition to ozone concentration, stomatal ozone flux is not directly related to ozone concentration alone.

On-site observed hourly climate and ozone data was obtained for the sites UK-Snowdon, UKHarwell, UK-Auchencorth, UK-Strath Vaich, Germany (DE)-Linden, Italy (IT)-Arconate, Spain (ES)-Tres Cantos, Sweden (SE)-Östad for the year 2010. These sites were selected to represent a gradient of ambient climatic and ozone conditions. The monthly mean ozone concentrations and mean diurnal profile for each site are shown in Figure 1 and full details of the site locations and descriptions, and a summary of meteorological data for 2010 are shown in the supplementary material (S2). The sites are rural, but of differing altitude and distance to pollutant sources. For the UK sites, climate data was obtained from the Environmental Change Network (http://data.ecn.ac.uk/index.asp), and ozone data was obtained from the UKAIR archive (http://uk-air.defra.gov.uk/data/). Ozone data from DE-Linden was obtained from the Hessian Air Quality Monitoring Network

(http://www.hlnug.de/messwerte/luft.html), with corresponding meteorological data from the Environmental Monitoring and Climate Impact Research Station at Linden (personal communication). Data from IT-Arconate were obtained from ARPA Lombardia (Agenzia Regionale per la Protezione dell'Ambiente) air quality monitoring network of the Lombardy region (hppt://www2.arpalombardia.it/sites/QAria/). Data from ES-Tres Cantos were obtained from an experimental station run by CIEMAT (García-Gómez et al., 2016). Data from SE-Östad were obtained from local meteorological measurements on site; where needed interpolated daily values for Östad were used to fill gaps in data, obtained from official statistics on the web-site of the Swedish Meteorological and Hydrological Institute. For each of these sites, stomatal ozone fluxes for each species were calculated over the period JanuaryDecember using the $\mathrm{DO}_{3} \mathrm{SE}$ version 3.03 model (Emberson et al., 2000a; LRTAP Convention, 2017, https://www.sei-international.org/do3se) using these climate and ozone data as meteorological inputs as the 'current' scenario. We appreciate that in some parts of Europe the species will not be in leaf for the entire year. As the time window of active growth varies between sites and years and will change in a future climate, showing theoretical fluxes for the whole year provides conceptual understanding of the potential for changes during earlier springs and later autumns as climates warm.

Stomatal ozone uptake was also calculated using the same set of meteorological data, but with hourly ozone values increased by 5 ppb above ambient values when ozone was $<40 \mathrm{ppb}$ 
and decreased by $5 \mathrm{ppb}$ when ambient values were $>45 \mathrm{ppb}$ ( 2100 ozone scenario). These changes are simplified, but similar to the overall model predictions for Europe for 2100 using the RCP6 emission scenario (Coleman et al., 2013), which shows decreased peak ozone concentrations of up to $8 \mathrm{ppb}$ in parts of Europe in 2100 compared to current conditions. Additional model runs were also made using reduced rainfall, with hourly rainfall when it occurred decreased by $20 \%$ (-20\% rain scenario), and with hourly temperature increased by $2^{\circ} \mathrm{C}\left(+2{ }^{\circ} \mathrm{C}\right.$ scenario). To compensate for the increase in VPD associated with increased temperature, in model runs where temperature was increased by $2^{\circ} \mathrm{C}$, VPD was also increased by $13 \%$. This was calculated as representing the increase in VPD that would occur within the range $20-30{ }^{\circ} \mathrm{C}$ and at relative humidity of $50 \%$, as relative humidity data was not available from all sites to allow this to be calculated directly. The ozone and climatic features of the model runs are summarised in Table 1. In all model runs, rather than $\mathrm{DO}_{3} \mathrm{SE}$ reading in soil moisture as an input, soil moisture was modelled by $\mathrm{DO}_{3} \mathrm{SE}$ from rainfall data, assuming a loam soil for consistency. The soil moisture module of $\mathrm{DO}_{3} \mathrm{SE}$ is based on the PenmanMonteith model of evapotranspiration (Monteith, 1965) and uses hourly plant transpiration, soil evaporation and intercepted canopy evaporation (Büker et al., 2012).

Table 1: Summary of the ozone and climate features of the model runs performed. In each scenario '2010' indicates measured values at the sites in 2010. The 2100 ozone scenario is simulated, but based on the 2010 values at each site. Temperature, VPD and rainfall are also based on measured 2010 values, but for some scenarios each hourly value has been modified by $+2{ }^{\circ} \mathrm{C},+13 \%$ or $-20 \%$ respectively.

\begin{tabular}{lllll}
\hline $\begin{array}{l}\text { Scenario name } \\
\text { (abbreviated) }\end{array}$ & Ozone & Temperature & VPD & Rainfall \\
\hline Current & 2010 & 2010 & 2010 & 2010 \\
2100 profile & 2100 simulation & 2010 & 2010 & 2010 \\
$+2{ }^{\circ} \mathrm{C}$ & 2010 & $2010+2^{\circ} \mathrm{C}$ & $2010+13 \%$ & 2010 \\
$-20 \%$ rain & 2010 & 2010 & 2010 & $2010-20 \%$ \\
$+2{ }^{\circ} \mathrm{C},-20 \%$ rain & 2100 simulation & $2010+2^{\circ} \mathrm{C}$ & $2010+13 \%$ & $2010-20 \%$ \\
2100 profile $+2{ }^{\circ} \mathrm{C}$ & 2100 simulation & $2010+2^{\circ} \mathrm{C}$ & $2010+13 \%$ & 2010 \\
2100 profile $-20 \%$ rain & 2100 simulation & 2010 & 2010 & $2010-20 \%$ \\
\hline
\end{tabular}



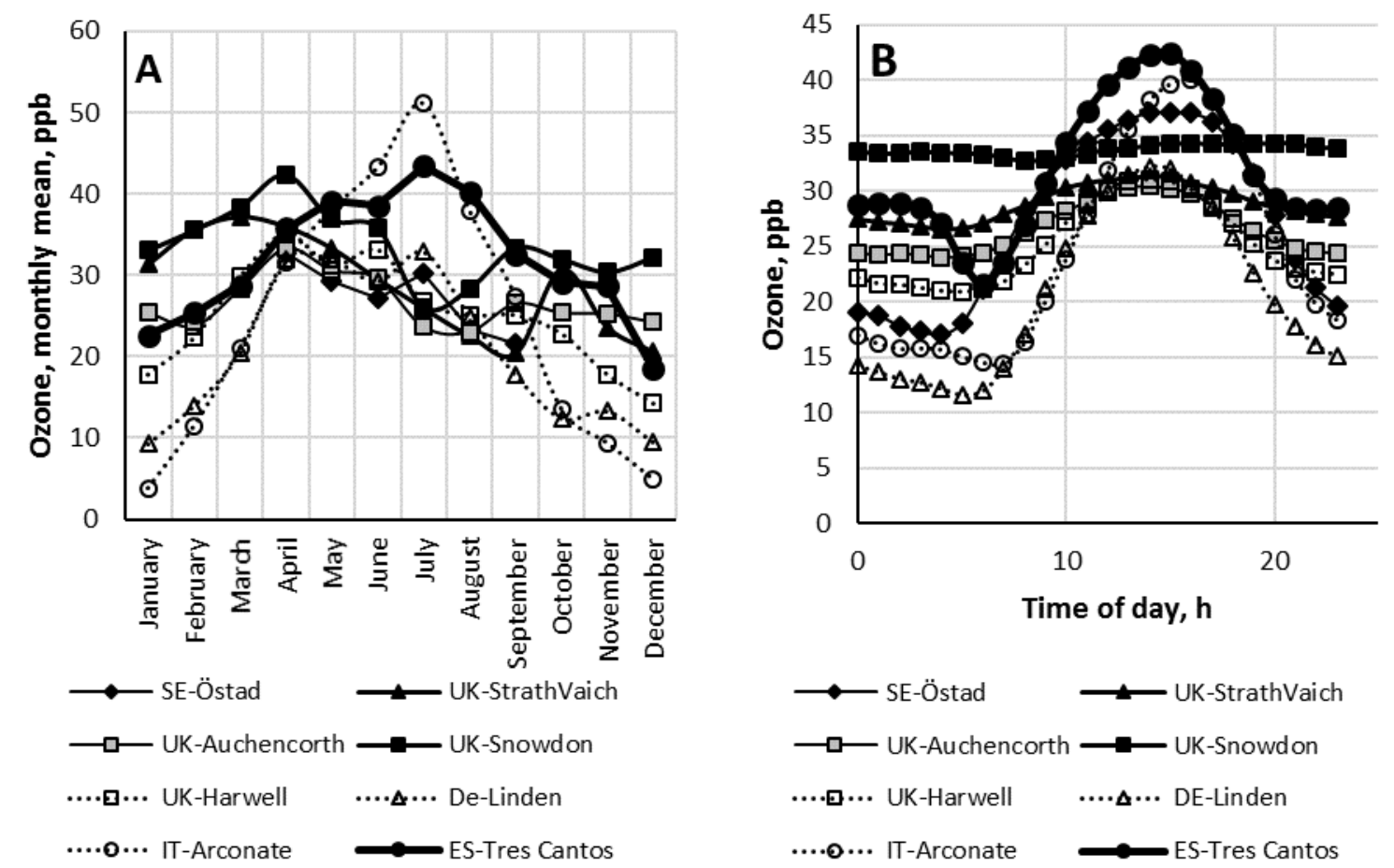

Figure 1: a) Monthly mean ozone profile and b) Mean diurnal ozone profile for the sites used in this study, based on hourly ozone data from 2010, Jan $1^{\text {st }}-$ Dec $31^{\text {st }}$. Note, data for SEÖstad was available for April to September only.

\section{Results \\ Ozone concentrations and flux ( $\left.\mathrm{POD}_{0}\right)$ in 2010}

Almost all sites (except IT-Arconate and ES-Tres Cantos) had a 'spring peak' of ozone concentration, with the highest concentrations in March/April (Figure 1a). This pattern is common in Europe due to the seasonal variations in precursor emissions, the strength of the stratospheric source, and the balance between photochemical production and destruction of ozone (Royal Society, 2008). Diurnal ozone concentrations generally peaked in midafternoon, with lowest concentrations between midnight and 06:00 (Figure 1b). However, the amplitude between the minimum and maximum ozone concentration was variable with some sites having an amplitude of $25 \mathrm{ppb}$ (e.g. IT-Arconate) and some showing little variation (e.g. UK- Snowdon and UK-Strath Vaich). The sites at highest altitude had higher night-time and winter-time ozone concentrations compared to those at lower altitude, which is a recognised pattern due to losses from dry-deposition being replaced from ozone-rich layers above (Royal Society, 2008). The monthly total ozone flux (POD) showed very different patterns between the different sites (Figure 2). The most northern sites, from the UK and Sweden, had the highest ozone fluxes in the summer months, when the ozone values were typically 5-10 ppb lower than those of the spring maxima. Interestingly, ozone fluxes calculated for D. glomerata between May and August were similar in SE-Östad to those of IT-Arconate despite large differences in ozone concentration and climate during this time period. For perennial grassland species such as D. glomerata (Figure 4) and L. hispidus (Figure 5), the $\mathrm{DO}_{3} \mathrm{SE}$ model predicted that stomatal ozone uptake could take place almost all year round at most sites, as meteorological conditions are conducive to stomatal opening. However, it is important to note that stomatal uptake for birch (Figure 3) would be limited to when leaves are present. Similarly, overwintering leaves of D. glomerata and L. hispidus may not be physiologically active during the winter months. Modelled total annual stomatal 
ozone uptake for the different climate and ozone scenarios for B. pendula, D. glomerata and L. hispidus are shown in supplementary material (S4).

Frequently at all sites, the periods of highest stomatal ozone fluxes did not coincide with the periods of highest ozone concentration, for example DE-Linden and ES-Tres Cantos had the highest ozone concentrations in summer whereas stomatal ozone fluxes were higher in spring (Supplementary material Figure S2). In many cases during the year such differences may be explained by limitations due to soil moisture availability, which are apparent when comparing model runs with and without soil moisture deficit induced reductions in stomatal ozone uptake. These show that soil moisture deficit at some sites can reduce stomatal ozone flux, with several sites showing reductions of over $50 \%$ during some months compared to fluxes under field capacity conditions (Supplementary material S3).

The majority of the total stomatal ozone flux ( $\left.\mathrm{POD}_{0}\right)$ occurred with ozone values between 20 and $50 \mathrm{ppb}$ at all sites for both the 'current' and 2100 ozone profiles (Figure 6). The contribution to total stomatal ozone uptake from ozone concentrations above $50 \mathrm{ppb}$ was comparatively low, with the exception of IT-Arconate, which had the highest ozone concentrations during the summer months and $25-50 \%$ of the total ozone flux was attributed to ozone values $>50 \mathrm{ppb}$. Using the 2100 ozone scenario there was a significantly lower contribution to total stomatal ozone uptake from ozone values of 10-20 ppb for all species $(\mathrm{p}<0.05, \mathrm{p}<0.01, \mathrm{p}<0.05$ for B. pendula, D. glomerata and L. hispidus respectively). There was also a significantly lower contribution from ozone values of $0-10 \mathrm{ppb}$ for $D$. glomerata $(\mathrm{p}<0.05)$ and L. hispidus $(\mathrm{p}<0.05)$ and from ozone values of 20-30 ppb for D. glomerata $(\mathrm{p}<0.01)$ and L. hispidus $(\mathrm{p}<0.05)$. In contrast, there was a significantly higher contribution from ozone values of $40-50 \mathrm{ppb}$ in the 2100 compared to the current scenario for all species $(p<0.001)$. At higher ozone concentrations there was a significantly lower contribution to stomatal ozone uptake in the 2100 ozone scenario in the categories 50-60 ppb (B. pendula, $\mathrm{p}<0.05), 60-70 \mathrm{ppb}(\mathrm{p}<0.05$ for all species) and 70-80 ppb (L. hispidus, $\mathrm{p}<0.05)$.

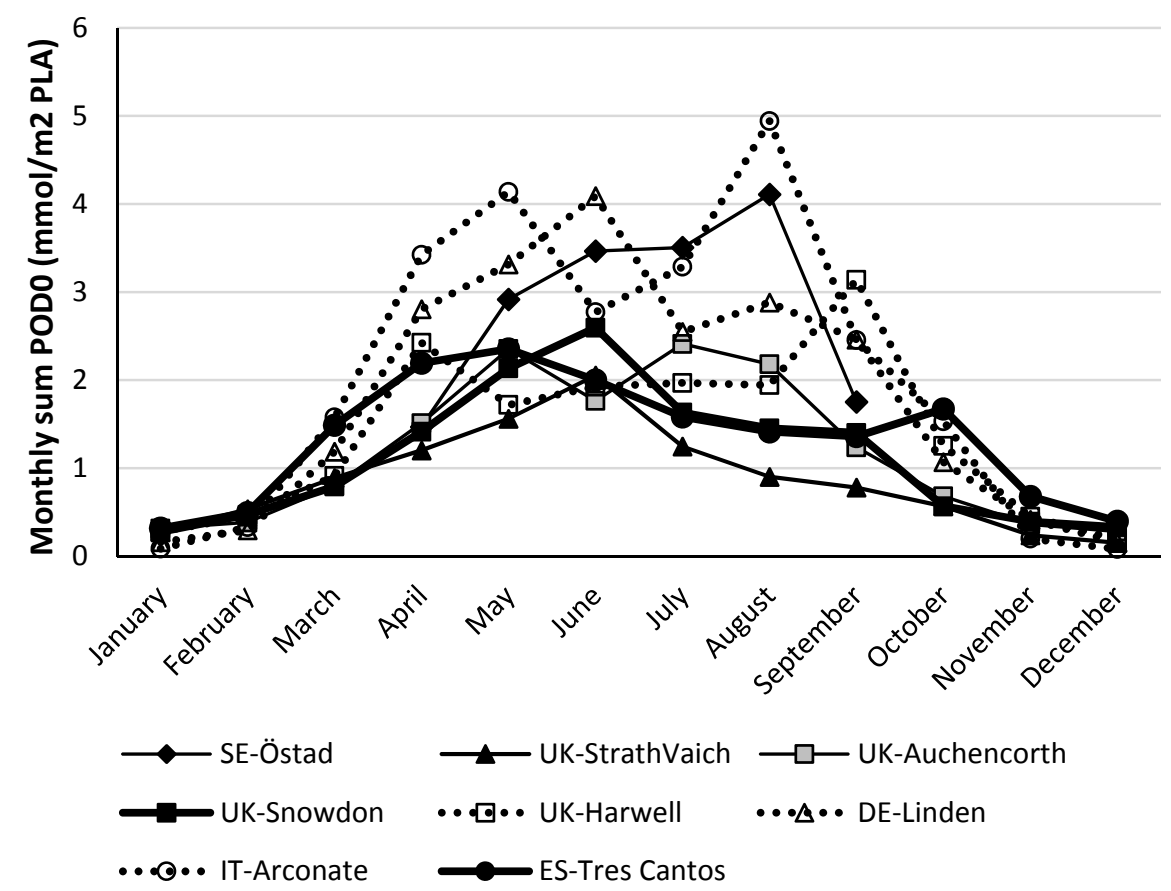

Figure 2: Monthly stomatal ozone uptake ( $\mathrm{POD}_{0}, \mathrm{mmol} \mathrm{m}^{-2}$ per month) for D. glomerata in current (2010) ozone and climate conditions at all sites. 


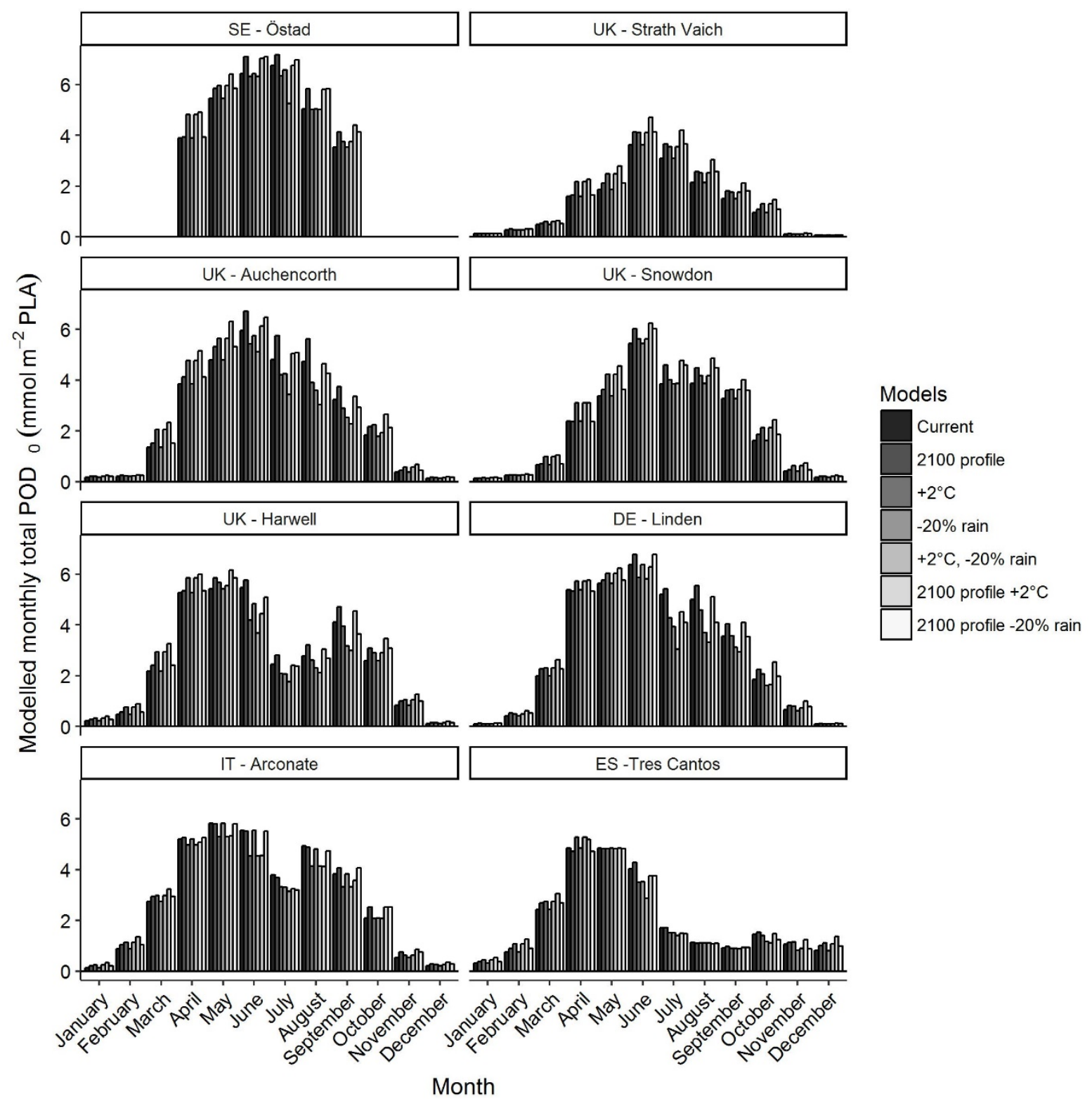

Month

Figure 3: Modelled monthly total stomatal ozone uptake ( $\mathrm{POD}_{0}, \mathrm{mmol} \mathrm{m}^{-2}$ per month) for $B$. pendula at selected European sites in 2010. Note: Whilst year round fluxes are provided for comparison with Figure 3 and 4, it is important to note that the leaves of B. pendula are shed from trees in the autumn, with bud-burst occurring in the spring with the date depending on 299 location. 


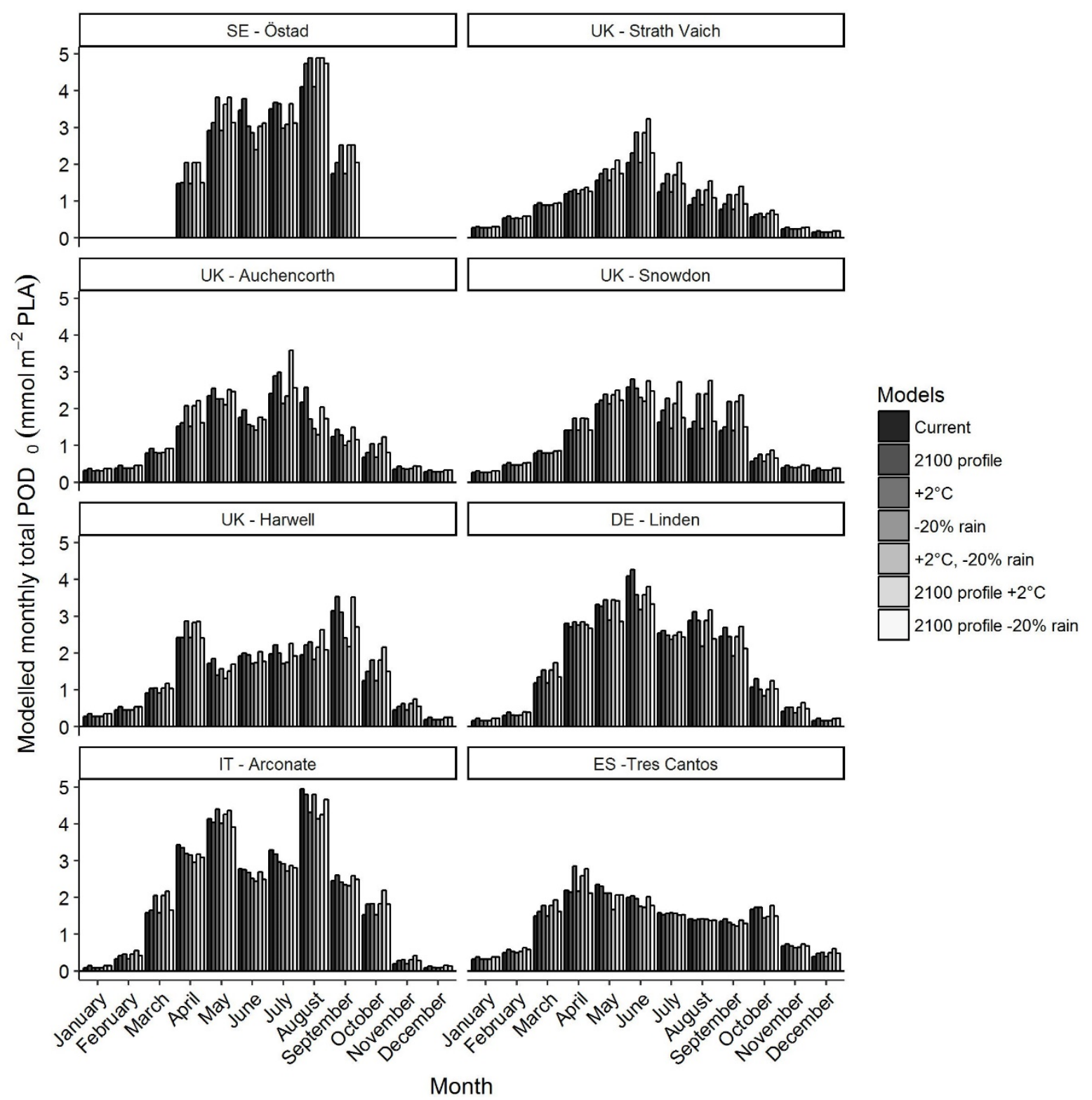

Figure 4: Modelled monthly total stomatal ozone uptake ( $\mathrm{POD}_{0}, \mathrm{mmol} \mathrm{m}^{-2}$ per month) for $D$. 302 glomerata at selected European sites in 2010. 


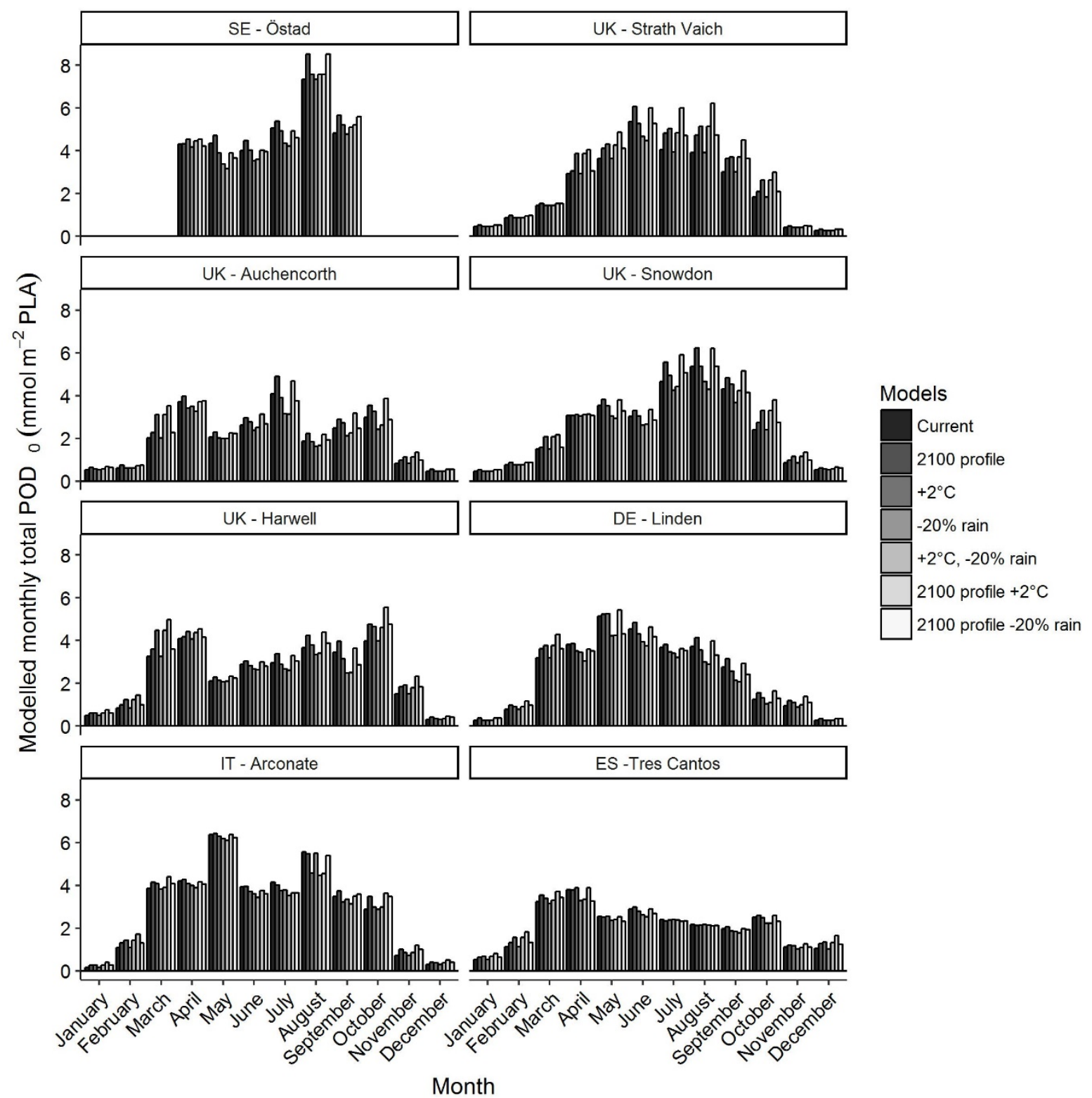

Month

304 Figure 5: Modelled monthly total stomatal ozone uptake ( $\mathrm{POD}_{0}, \mathrm{mmol} \mathrm{m}^{-2}$ per month) for $L$. 305 hispidus at selected European sites in 2010. 


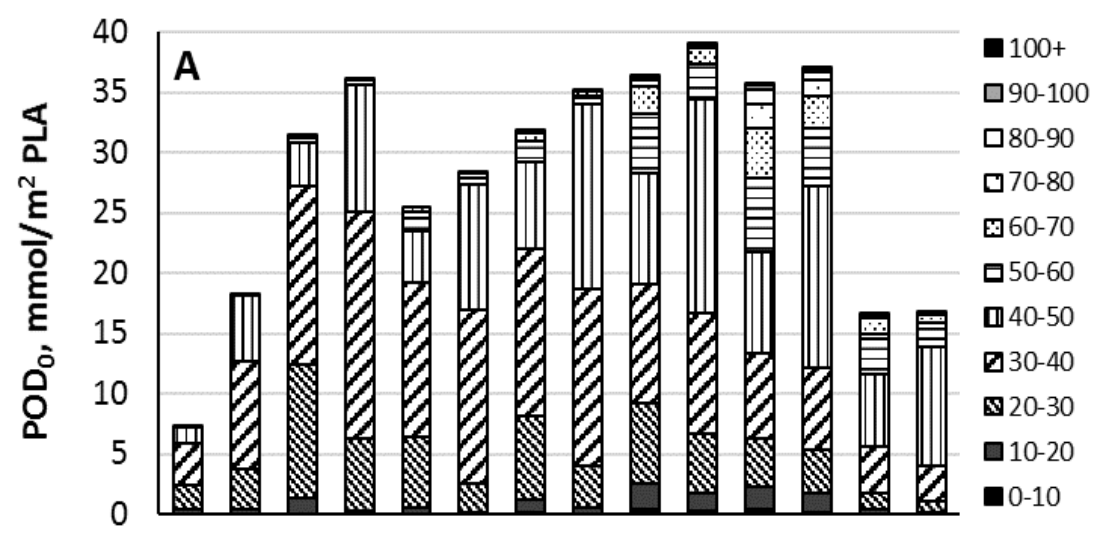

306
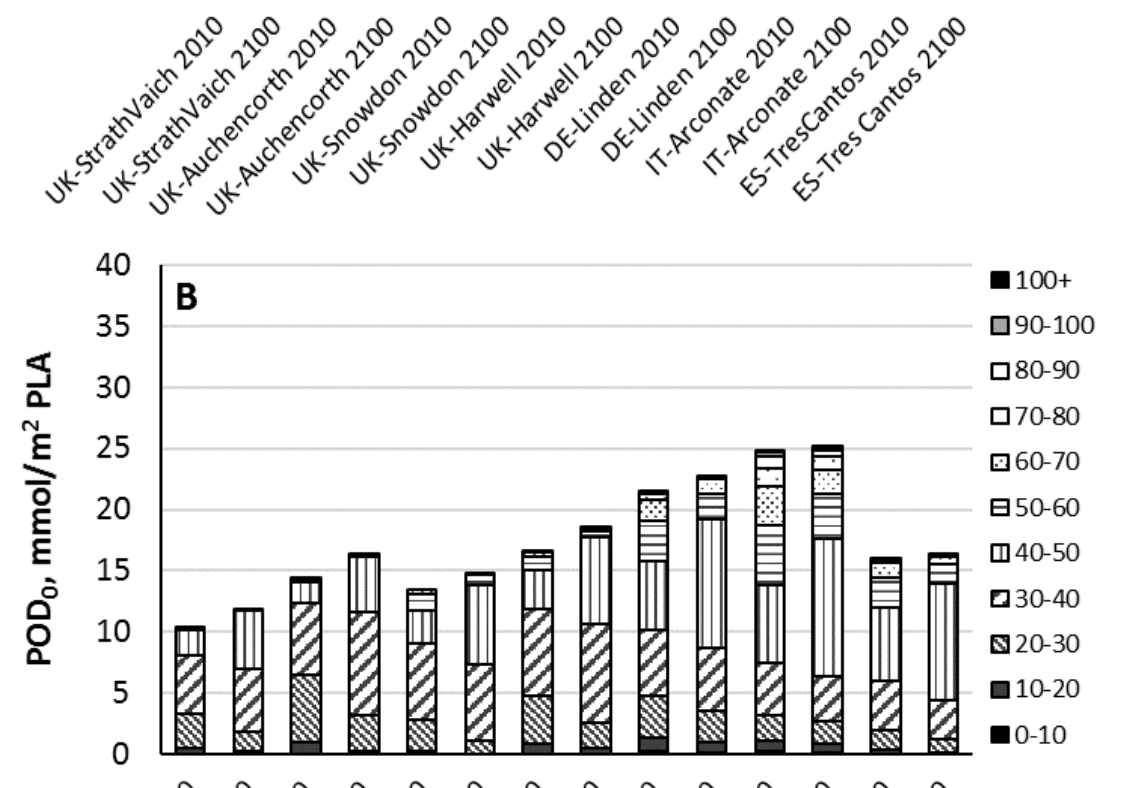

307
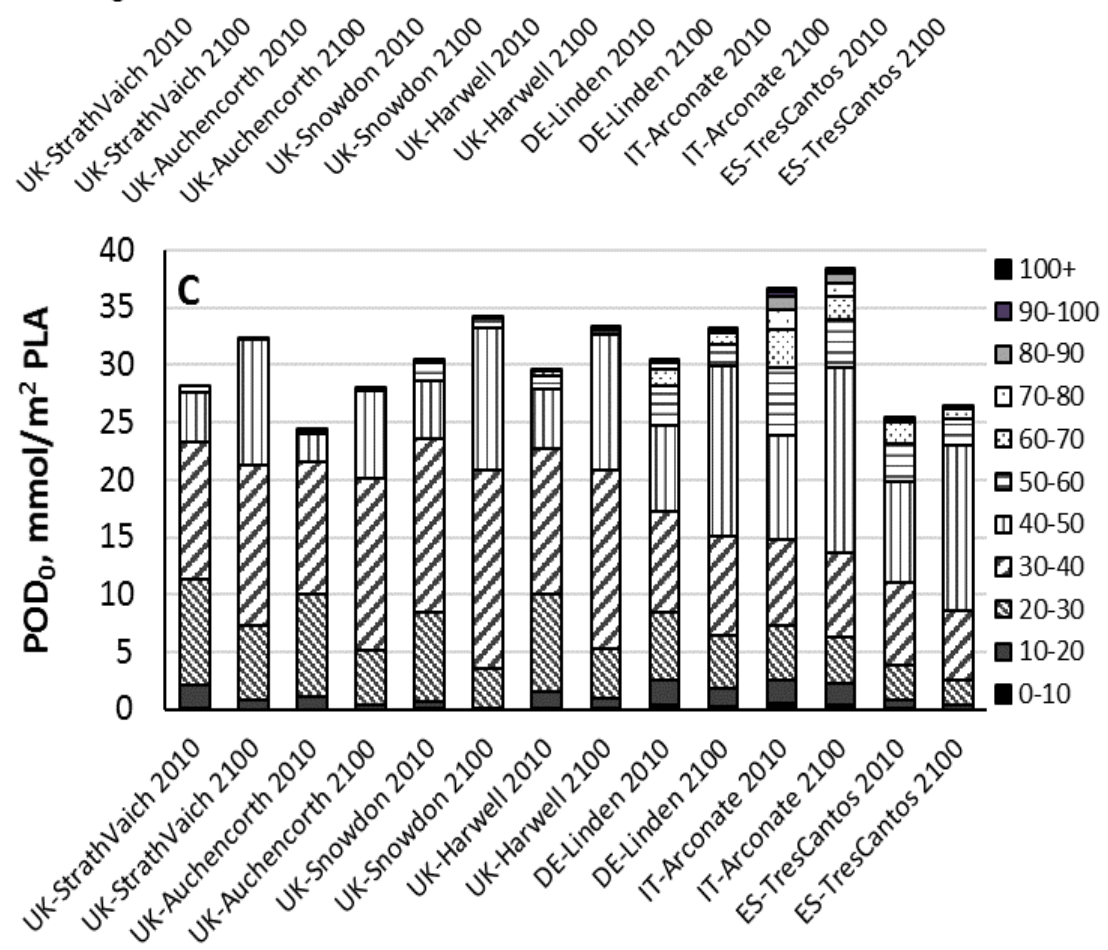

Figure 6: Total stomatal ozone flux from different categories of ozone concentration for A) B. pendula, B) D. glomerata and C) L. hispidus for the different sites, using the current and 2100 ozone profiles. (annual data is not available for Sweden-Östad). 


\section{Consequences of changes in ozone profile}

314 The 2100 ozone profile, with increased background and decreased peaks, resulted in increased $24 \mathrm{~h}$ mean ozone values at all sites of 1 to $4 \mathrm{ppb}$ (full details are shown in Supplementary material S4). The $\mathrm{DO}_{3} \mathrm{SE}$ model predicted that this would increase annual stomatal ozone uptake by as much as $14-18 \%$ at northern sites e.g. UK-Strath Vaich (Figure 6). In southern Europe, the increase in annual stomatal ozone uptake was lower ( $3 \%$ increase for $B$. pendula at IT-Arconate), partly because the higher hourly ozone concentrations of the 'current' dataset at these sites meant that the increase in background ozone concentrations was offset by decreases in peaks (current vs 2100 ozone profiles for all sites are shown in Supplementary material S4). The percentage increase in ozone flux using the 2100 profile compared to current was linearly related to latitude (Figure $7: \mathrm{r}^{2}=0.90$ for $B$. pendula, $\mathrm{r}^{2}=0.92$ for $L$. hispidus and $\mathrm{r}^{2}=0.81$ for D. glomerata), with a similar relationship with latitude for the percentage increase in ozone concentration $\left(\mathrm{r}^{2}=0.83\right)$.

The extent of additional ozone uptake due to the changing ozone profile varied throughout the year. For the majority of sites the increase in ozone flux was largest during the summer and autumn (Figures 3-5). Climate (particularly temperature) tended to limit stomatal opening in spring so that ozone fluxes were comparatively unaffected by an increase in ozone concentration, unless temperature was also increased.

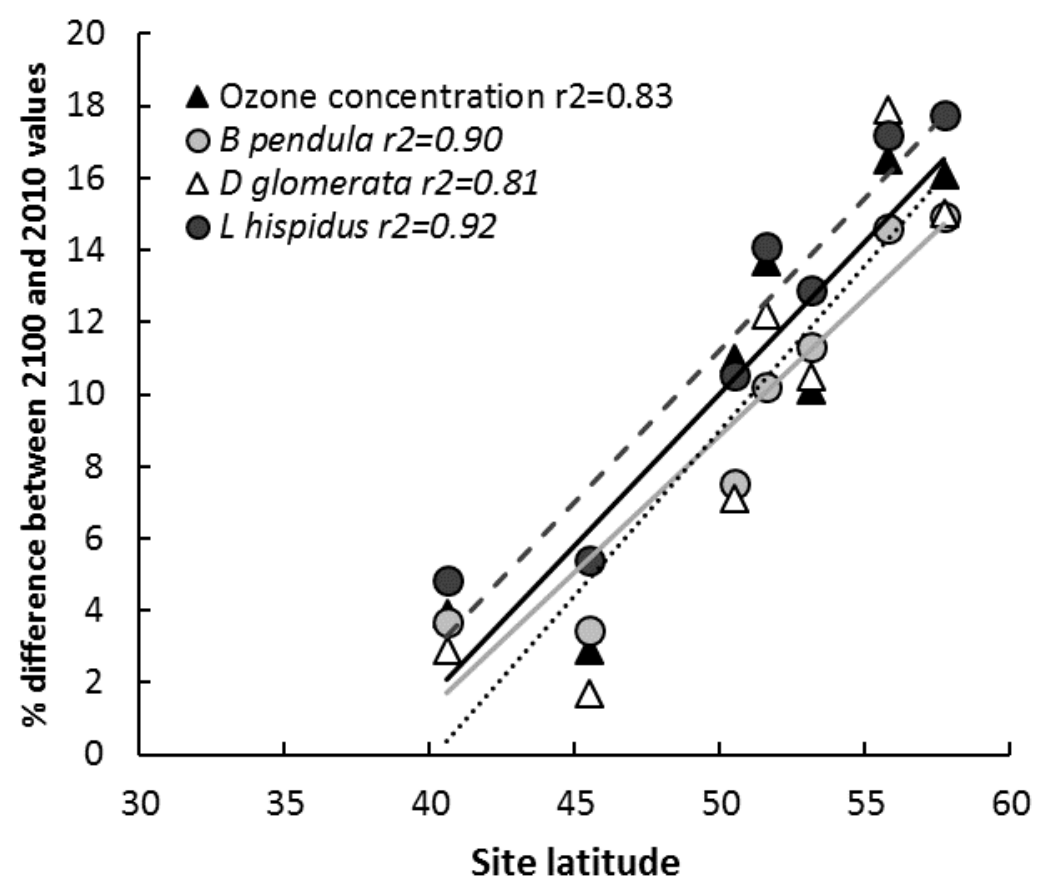

Figure 7: Percentage increase in ozone flux with the 2100 ozone profile compared to 2010 ozone for L. hispidus, D. glomerata and B. pendula at the different sites. The percentage increases in ozone concentration with the 2100 ozone profile compared to 2010 (based on $24 \mathrm{~h}$ mean concentrations) are also shown. Note these do not include SE-Östad as the model runs for this site did not include the full 12 months. $-=$ ozone concentration, $-=B$. pendula, $--=$ L. hispidus and $\cdots=$ D. glomerata. 
An increase in temperature of $2^{\circ} \mathrm{C}$ increased stomatal ozone uptake at all sites and had a larger impact than changing ozone profile in many cases (Figures 3-5), particularly for $B$. pendula $(\mathrm{p}<0.01)$ and L. hispidus $(\mathrm{p}<0.01)$. For IT-Arconate and ES-Tres Cantos there was a spring. The other sites showed increases in stomatal ozone uptake with increased temperature over a wider time-period, and although these were sometimes largest in spring (March to May), they also sometimes occurred in summer and/or autumn. D. glomerata has a higher $\mathrm{T}_{\min }$ than L. hispidus and $B$ pendula and for this species increasing temperature by $2{ }^{\circ} \mathrm{C}$ in the spring was not sufficient for $\mathrm{T}_{\min }$ to be reached, particularly in the more northern sites, and therefore there was no increase in stomatal opening. However, for L. hispidus and B. pendula the increase in temperature caused a shift from $\mathrm{T}_{\min }$ towards $\mathrm{T}_{\text {opt }}$ and therefore an increase in stomatal opening.

Soil moisture limitations in the current climate were sufficient to reduce stomatal ozone uptake for L. hispidus and D. glomerata during the summer for prolonged periods at the sites IT-Arconate, ES-Tres Cantos and UK-Harwell, and for a shorter time at DE-Linden (Supplementary material S3). A reduction in rainfall by $20 \%$ reduced stomatal ozone uptake in some months at all sites, including those with high annual rainfall. For the sites ITArconate and ES-Tres Cantos the reduction in stomatal ozone uptake due to reduced rainfall was lower than for the other sites, because stomatal fluxes were already limited by soil moisture in 'current' conditions. Reductions in rainfall by $20 \%$ had very little impact on the stomatal ozone uptake of $B$. pendula at any of the sites used, because the stomatal conductance model parameterisation indicated that this species maintained stomatal opening at low soil water potential.

\section{Consequences of combined changes in ozone and climate in 2100}

A combination of a $2^{\circ} \mathrm{C}$ increase in temperature and 2100 ozone profile increased stomatal ozone uptake, although the magnitude of the increase varied. For L. hispidus at the sites UKHarwell, IT-Arconate, ES-Tres Cantos and DE-Linden, the impact was largest in March and was much less in the summer, when other factors were limiting stomatal fluxes. For UKStrath Vaich, UK-Snowdon, UK-Auchencorth and SE-Östad the combination of $2^{\circ} \mathrm{C}$ increase in temperature and 2100 ozone scenario corresponded with increased fluxes throughout most of the year and the impact was largest in summer and autumn. A combination of $20 \%$ decreased rainfall and 2100 ozone profile often gave monthly stomatal ozone fluxes that were intermediate between those of 2100 ozone profile and decreased rainfall, therefore, the monthly stomatal ozone uptake with this scenario were usually higher than those of the 'current' scenario.

\section{$\underline{\text { Species-specific considerations }}$}

Calculated ozone fluxes were highest for L. hispidus and B. pendula, with D. glomerata fluxes generally lower at all sites. This is partly because $L$ hispidus had a higher $g_{\max }$ than the other species and therefore higher stomatal conductance, but $L$. hispidus and B. pendula also had a lower $T_{\min }$, enabling stomatal uptake at lower temperatures than for D. glomerata. This difference in response to meteorological conditions also meant that the seasonal profile of stomatal ozone flux was different for the different species, with $D$. glomerata having a more pronounced seasonal variation.

Identification of the minimum ozone concentration with a corresponding stomatal ozone uptake rate reveals that for $B$. pendula, ozone fluxes above the commonly used threshold of 1 
nmol $\mathrm{m}^{2} \mathrm{~s}^{1}\left(\mathrm{POD}_{1}\right)$ accumulated when ozone values were $>10 \mathrm{ppb}$, if climatic conditions were optimal. Although ozone flux could be high when ozone concentrations were higher than $50 \mathrm{ppb}$, often climatic conditions were limiting. For L. hispidus, B. pendula and D. glomerata, ozone flux could be above the threshold of $1 \mathrm{nmol} \mathrm{m} \mathrm{s}^{-1}{ }^{1}$ when ozone values were as low as 5 ppb, 10 ppb and 10 ppb respectively (Supplementary material S5).

\section{Discussion}

This study has shown that without any change in climate, increased background and reduced peak ozone concentrations typically predicted for Europe in 2100 as a result of increased hemispheric transport of precursors and local precursor emission reductions could result in up to a $15 \%$ increase in total stomatal ozone uptake to vegetation ( $\mathrm{POD}_{0}$ ) compared to 2010 ozone profiles. The north-south gradient in ozone concentration for the sites meant that the impacts of the future ozone scenario varied with latitude. In more northern sites where peak ozone concentrations were lower, a higher proportion of hourly ambient ozone values were less than $40 \mathrm{ppb}$ and the applied scenario therefore increased the ozone concentration as a result of the increasing background. In contrast, the southern European sites had higher peaks of ozone in current conditions and therefore there was a larger effect of the reduction in values $>45 \mathrm{ppb}$ by $5 \mathrm{ppb}$ on the ozone concentrations with the 2100 scenario. Although all sites showed a net increase in mean ozone concentration and total stomatal ozone uptake with the 2100 scenario compared to current conditions, the proportionate increase was lower in the southern sites. This indicates that a changing ozone profile in Europe could have a larger impact in mid and northern regions than southern regions, especially when the increased ozone concentrations coincide with climatic conditions favourable for ozone uptake.

Changes in meteorology as a consequence of predicted climate change could also have a large influence on stomatal ozone uptake in the absence of any alterations in ozone concentration, particularly temperature, which increased modelled stomatal ozone uptake at all sites in this study. In this study only a single stomatal conductance parameterisation per species was used across Europe and it is possible that vegetation of the Mediterranean region may exhibit a reduced extent of stomatal closure with high temperature, VPD and SWP compared to that grown in more northern regions (Calvo et al., 2007, LRTAP 2017) and therefore climatic conditions may be more favourable for stomatal ozone uptake than this modelling exercise suggests. The element of climate change having the largest influence on stomatal fluxes varied according to region. This is consistent with a previous study on winter wheat and beech, where increased ozone fluxes in response to increased temperature were predicted over the period 1997-2100 in Germany (Bender et al., 2015).

This study applied a simplified 2100 scenario for ozone and meteorological conditions in the future to provide an indication of potential implications for stomatal ozone flux. However, diurnal and seasonal variations in changes in both ozone and meteorological conditions may occur in 2100 which could influence stomatal fluxes. Higher daily maxima for temperature could enhance the rate of ozone formation as well as influencing the contribution of natural sources to precursor emissions (Royal Society, 2008), increasing hourly ozone values by 1-10 ppb (Jacob and Winner, 2009). There could also be feedbacks between the vegetation and ozone and microclimatic conditions, for example, reduced stomatal ozone uptake due to increased soil moisture deficit in 2100 could lead to increased ambient ozone concentrations, (Kroeger et al. 2014; Emberson et al. 2013).

The impact of increasing temperature on stomatal ozone fluxes could be particularly important for species that have a low $\mathrm{T}_{\mathrm{min}}$ and are actively growing in cooler conditions, 
where an increase in temperature would give conditions closer to optimum for conductance. As a consequence of predicted climate change, stomatal ozone fluxes could occur over a longer period of the year than in current conditions, including into early spring and autumn, which until recently have not been considered to be associated with a risk to vegetation from ozone pollution. It has been suggested that some species are most sensitive to ozone at or around the time of flowering (e.g. Pleijel et al., 1998, Soja et al., 2000) and ozone impacts on flowering and seed development have been shown for a wide range of species in a recent meta-analysis (Leisner and Ainsworth, 2012). Since many European species flower in March-April it is possible that these species are particularly at risk from future ozone and climate change scenarios. Spring flowering species have been poorly studied for ozone responses in northern Europe in comparison to those which flower in summer (Hayes et al., 2007). In addition, stomatal conductance model parameterisations are not available for many of these early flowering species, which may be active at lower temperatures than the species considered in this study. Further studies on spring flowering species are therefore needed to better understand the potential consequences of a changing ozone profile. In contrast, experiments in the Mediterranean region have focussed on spring flowering plants as this is the main flowering season in this region before conditions become too dry (GonzálezFernández et al., 2010, Calvete-Sogo et al., 2015).

Increased ozone fluxes to vegetation in autumn may also be important. It has been demonstrated that mature leaves of some tree species are more sensitive to ozone than those that are not fully-expanded in terms of both visible injury and impairment of photosynthesis (Zhang et al., 2010, Bagard et al., 2008). It is therefore possible that increased stomatal ozone uptake in autumn may damage leaves to a greater extent than a similar ozone uptake in spring if the leaves are more sensitive to ozone at this time. Ozone can also accelerate senescence (e.g. Matyssek and Sandermann, 2003), and if premature leaf loss occurs in the autumn there may be a longer period without leaves until the following spring. In addition, autumn exposure to ozone may decrease winter-hardiness of some species e.g. Picea abies due to changes in chloroplast shape and location within the cells (Kivimaenpaa et al., 2014). With increased background ozone concentrations these detrimental effects could be further enhanced as climatic conditions are favourable for uptake of additional ozone.

An aspect not considered in this study is that alterations in climate could also influence stomatal ozone fluxes due to changes in phenology. In Europe, a comprehensive analysis of a large phenological dataset has shown that the phenological response to climate change shows an advance in spring/summer of 2.5 days per decade (Menzel et al., 2006). Over the previous 60 years it has been demonstrated that bud-burst of beech, birch and oak is beginning increasingly earlier (Olsson, 2014), particularly at northern latitudes and it has been estimated that in Fennoscandia the growing season is extending by four days per decade (Hogda et al., 2013). This is particularly relevant for deciduous trees such as B. pendula because the current study has shown that climatic and ozone conditions in the early spring and late autumn months that are outside of the current growing period are also conducive to ozone uptake, should the growing season extend into these.

Ozone uptake exceeding $1 \mathrm{nmol} \mathrm{m}^{-2} \mathrm{~s}^{-1}$ (considered to be a surrogate ozone detoxification threshold for forest trees and semi-natural vegetation; Mills et al., 2011b) occurred with ozone concentrations at or below $10 \mathrm{ppb}$ for the species used in this study. This demonstrates that small but frequent increases to these low concentrations could result in large impacts on total ozone fluxes over the course of a growing season. However, the ozone concentration required to reach this threshold is related to the $g_{\max }$ of the species and species with a higher 
gmax reach this threshold at a lower ozone concentration, when climatic conditions are favourable. Due to the mis-match between high ozone concentrations and optimum climatic conditions for stomatal uptake, the species-specific minimum and optimum temperature for stomatal uptake were very influential in determining ozone fluxes, indicating that a robust parameterisation of $\mathrm{T}_{\min }$ is essential to ensure that stomatal ozone fluxes in sub-optimal climatic conditions can be accurately assessed.

This study has used example sites from across Europe to show that a future ozone profile in Europe with increased background ozone concentrations and decreased peaks can cause a significant increase in stomatal ozone flux to vegetation. In particular at mid- to northern latitudes, large increases in ozone flux are predicted for the summer months when climatic conditions are rarely limiting. In Southern Europe, our predictions using a generalized flux model parameterisation to facilitate comparisons suggest that the changing ozone profile would have proportionately less impact on accumulated flux. Although changes in temperature, soil moisture and ozone profile can all influence accumulated flux, a combination of an altered ozone profile together with a $2{ }^{\circ} \mathrm{C}$ increase in temperature gives a much larger increase in predicted stomatal ozone uptake than altered ozone profile alone. Furthermore, background ozone concentrations are also high during spring and autumn and increased impacts on vegetation during these periods may be biologically significant as some species may be more vulnerable at these times. The time window for considering vegetation at risk from ozone pollution in future scenarios should therefore be extended to include the active growing seasons in spring and autumn as significant ozone fluxes could occur during this time.

\section{References}

Akritidis, D., Zanis, P., Pytharoulis, I. \& Karacostas, Th. (2014). Near-surface ozone trends over Europe in RegCM3/CAMx simulations for the time period 1996-2006. Atmospheric Environment 97:6-18.

Alonso, R., Elvira, S., Castillo, F.J. \& Gimeno, B.S. (2001). Interactive effects of ozone and drought stress on pigments and activities of antioxidative enzymes in Pinus halepensis. Plant Cell and Environment 24:905-916.

Bagard, M., Le Thiec, D., Delacote, E., Hasenfratz-Sauder, M.P., Banvoy, J., Gerard, J., Dizengremel, P. \& Jolivet, Y. (2008). Ozone-induced changes in photosynthesis and photorespiration of hybrid poplar in relation to the developmental stage of the leaves. Physiologica Plantarum 134:559-574.

Bender, J., Bergmann, E., Weigel, H.-J., Grünhage, L., Schröder, M., Builtjes, P., Schaap, M., Kranenburg, R., Wichink Kruit, R., Stern, R., Baumgarten, M. \& Matyssek, R. (2015). Anwendung und Überprüfung neuer Methoden zur flächenhaften Bewertung der Auswirkung von bodennahem Ozon auf die Biodiversität terrestrischer Ökosysteme - Teil I. UBA-Texte $70 / 2015$.

Bender, J., Muntifering, R.B., Lin, J.C. \& Weigel, H.J. (2006). Growth and nutritive quality of Poa pratensis as influenced by ozone and competition. Environmental Pollution 142:109115 . 
Braun, S., Schindler, C. \& Rihm, B. (2014). Growth losses in Swiss forests caused by ozone:

Epidemiological data analysis of stem increment of Fagus sylvatica L. and Picea abies Karst. Environmental Pollution 192: 129-138.

Büker, P., Feng, Z., Uddling, J. et al. (2015). New flux based dose-response relationships for ozone for European forest tree species. Environmental Pollution 206:163-174.

Büker, P., Morrissey, T., Briolat, A., Falk, R., Simpson, D., Tuovinen, J.P., Alonso, R., Barth, S., Baumgarten, M., Grulke, N., Karlsson, P.E., King, J., Lagergren, F., Matyssek, R., Nunn, A., Ogaya, R., Penuelas, J., Rhea, L., Schaub, M., Uddling, J., Werner, W. \& Emberson, L.D. (2012). DO3SE modelling of soil moisture to determine ozone flux to forest trees. Atmospheric Chemistry and Physics 12:5537-5562.

Burkey, K.O., Neufeld, H.S., Souza, L., Chappelka, A.H. \& Davison, A.W. (2006). Seasonal profiles of leaf ascorbic acid content and redox state in ozone-sensitive wildflowers. Environmental Pollution 143:427-434.

Calvete-Sogo, H., Elvira, S., Sanz, J. et al. (2015). Current ozone levels threaten gross primary production and yield of Mediterranean annual pastures and nitrogen modulates the response. Atmospheric Environment 95:197-206.

Calvete-Sogo, H., Gonzalez-Fernandez, I., Garcia-Gomez, H., Alonso, R., Elvira, S., Sanz, J. \& Bermejo-Bermejo, V. (2017). Developing ozone critical levels for multi-species canopies of Mediterranean annual pastures. Environmental Pollution 220:186-195.

Calvo, E., Martin, C. \& Sanz, M.J. (2007). Ozone sensitivity differences in five tomato cultivars: Visible injury and fruits. Water Air and Soil Pollution 186:167-181.

Clifton, O.E., Fiore, A.M., Correa, G., Horowitz, L.W. \& Naik, V. (2014). Twenty-first century reversal of the surface ozone seasonal cycle over the northeastern United States. Geophysical Research Letters 2014:7343-7350.

Coleman, L., Martin, S., Varghese, S.G., Jennings, C.D. et al. (2013). Assessment of changing meteorology and emissions on air quality using a regional climate model: Impact on ozone. Atmospheric Environment 69:198-210.

Coyle, M., Fowler, D. \& Ashmore, M. (2003). New directions: Implications of increasing tropospheric background ozone concentrations for vegetation. Atmospheric Environment 37 , 153-154.

Diem, J.E. (2004). Explanations for the spring peak in ground-level ozone in the southwestern United States. Physical Geography 25:105-129.

EEA (2011). Air pollution by ozone across Europe during summer 2010. EEA technical report number 6/2011. EEA, Copenhagen, Denmark. doi:10.2800/77390

Emberson, L.D., Kitwiroon, N., Beevers, S., Büker, P. \& Cinderby, S. (2013). Scorched Earth: how will changes in the strength of the vegetation sink to ozone deposition affect human health and ecosystems? Atmospheric Chemistry and Physics 13:6741-6755. 
Emberson, L.D., Ashmore, M.R., Cambridge, H.M., Simpson, D. \& Tuovinen, J.-P. (2000a). Modelling stomatal ozone flux across Europe. Environmental Pollution, 109:403-413.

Emberson, L.D., Wieser, G. \& Ashmore, M.R. (2000b). Modelling of stomatal conductance and ozone flux of Norway Spruce: comparison with field data. Environmental Pollution 109:393-402.

Fiore, A.M., Naik, V., Spracklen, D.V., Steiner, A., Unger, N., Prather, M., Bergmann, D., Cameron-Smith, P.J., Cionni, I. \& Collins, W.J. (2012). Global air quality and climate. Chemical Society Reviews 41:6663-6683.

García-Gómez, H., Aguillaume, L., Izquieta-Rojano, S., Valino, F., Avila, A., Elustondo, D., Santamaria, J.M., Alastuey, A., Calvete-Sogo, H., González-Fernández, I. \& Alonso, R. (2016). Atmospheric pollutants in peri-urban forests of Quercus ilex: evidence of pollution abatement and threats for vegetation. Environmental Science and Pollution Research 23:6400-6413.

González-Fernández, I., Bermejo, V., Elvira, S., Sanz, J. \& Gimeno, B.S. (2010). Modelling annual pasture dynamics: Application to stomatal ozone deposition. Atmospheric

Environment 44:21-22.

612

613 Harmens, H., Hayes, F., Mills, G., Sharps, K., Osborne, S. \& Pleijel, H. (2018). Wheat yield

\section{Atmospheric Environment 173: 1-5.}

Hayes, F., Mills, G., Harmens, H. \& Wyness, K. (2011). Within season and carry-over effects following exposure of grassland species mixtures to increasing background ozone. Environmental Pollution 159:2420-2426.

Hayes, F., Jones, M.L.M., Mills, G. \& Ashmore, M. (2007). Meta-analysis of the relative sensitivity of semi-natural vegetation species to ozone. Environmental Pollution 146:754762.

Hayes, F., Mills, G., Jones, M.L.M. \& Ashmore, M. (2010). Does a simulated upland community respond to increasing background, peak or accumulated exposure of ozone? Atmospheric Environment 44(34), 4155-4164.

Hogda, K.A., Tommervik, H. \& Karlsen, S.R. (2013). Trends in the start of the growing season in Fennoscandia 1982-2011. Remote Sensing 5:4304-4318.

IPCC (2014). Climate Change 2014: Synthesis Report. Contribution of Working Groups I, II and III to the Fifth Assessment Report of the Intergovernmental Panel on Climate Change [Core Writing Team R.K. Pachauri and L.A. Meyer (Eds.)]. IPCC, Geneva, Switzerland. $151 \mathrm{pp}$.

Jacob, D.J. \& Winner, D.A. (2009). Effect of climate change on air quality. Atmospheric Environment 43:51-63. 
Jarvis, P.G. (1976). Interpretation of variations in leaf water potential and stomatal conductance found in canopies in field. Philosophical transactions of the Royal Society of London Series B-Biological Sciences 273(927), 593-610.

Karlsson, P.E., Klingberg, J., Engardt, M., Andersson, C., Langner, J., Pihl-Karlsson, G. \& Pleijel, H. (2017). Past, present and future concentrations of ground-level ozone and potential impacts on ecosystems and human health in northern Europe. Science of the Total Environment 576:22-35.

Karlsson, P.E., Tang, L., Sundberg, J., Chen, D., Lindskog, A. \& Pleijel, H. (2007). Increasing risk for negative ozone impacts on vegetation in northern Sweden. Environmental Pollution 150:96-106.

Karlsson, P.E., Pleijel, H. \& Simpson, D. (2009). Ozone exposure and impacts on vegetation in the Nordic and Baltic countries. AMBIO: A Journal of the Human Environment 38:402405.

Kivimaenpaa, M., Riikonen, J., Sutinen, S. \& Holopainen, T. (2014). Cell structural changes in the mesophyll of Norway spruce needles by elevated ozone and elevated temperature in open-field exposure during cold acclimation. Tree Physiology 34:389-403.

Klingberg, J., Engardt, M., Uddling, J., Karlsson, P.E. \& Pleijel, H. (2011). Ozone risk for vegetation in the future climate of Europe based on stomatal ozone uptake calculations. Tellus A 63:174-187.

Klingberg, J., Bjorkman, M.P., Pihl-Karlsson, G. \& Pleijel, H. (2009). Observations of Ground-level ozone and $\mathrm{NO}_{2}$ in Northernmost Sweden, including the Scandian Mountain Range. Ambio 38:448-451.

Kroeger, T., Escobedo, F.J., Hernandez, J.L., Varela, S., Delphin, S., Fisher, J.R.B. \& Waldron, J. (2014). Reforestation as a novel abatement and compliance measure for groundlevel ozone. Proceedings of the National Academy of Sciences of the United States of America 111: E4204-E4213.

Lacressonniere G, Peuch VH, Vautard R, Arteta J, Deque M, Joly M, Josse B, Marecal V, Saint-Martin D. (2014). European air quality in the 2030's abd 2050's: Impacts of global and regional emission trends and of climate change. Atmospheric Environment 92:348-358.

Lee, Y., Wenig, M. \& Yang, X. (2009). The emergence of urban ozone episodes in autumn and air temperature rise in Hong Kong. Air Quality, Atmosphere and Health 2:111-121.

Lefohn, A.S., Malley, C.S., Simon, H., Wells, B., Xu, X.B., Zhang, L. \& Wang, T. (2017). Responses of human health and vegetation exposure metrics to changes in ozone concentration distributions in the European Union, United States and China. Atmospheric Environment 152:123-145.

Leisner \& Ainsworth, E.A. (2012). Quantifying the effects of ozone on plant reproductive growth and development. Global Change Biology 18, 606-616 
LRTAP Convention (2014). Manual on methodologies and criteria for modelling andmapping Critical Loads and Levels and air pollution effects, risks and trends. Chapter 3: Mapping critical levels for vegetation. http://icpvegetation.ceh.ac.uk

Massman, W.J. (1998). A review of the molecular diffusivities of $\mathrm{H}_{2} \mathrm{O}, \mathrm{CO}_{2}, \mathrm{CH}_{4}, \mathrm{CO}, \mathrm{O}_{3}$, $\mathrm{SO}_{2}, \mathrm{NH}_{3}, \mathrm{~N}_{2} \mathrm{O}, \mathrm{NO}$, and $\mathrm{NO}_{2}$ in air, $\mathrm{O}_{2}$ and $\mathrm{N}_{2}$ near STP. Atmospheric Environment 32, 1111- 1127

Matyssek, R. \& Sandermann, H. (2003). Impact of ozone on trees: an ecophysiological perspective. Progress in botany 64. Springer-Verlag. Heidelberg. pp349-404.

Menzel, A., Sparks, T.H., Estrella, N., Koch, E., Aasa, A., Ahas, R., Alm-Kuebler, K., Bissolli, P., Braslavska, O. et al. (2006). European phenological response to climate change matches the warming pattern. Global Change Biology 12:1969-1976.

Mills, G., Hayes, F., Simpson, D., Emberson, L., Norris, D., Harmens, H., Büker, P. (2011a). Evidence of widespread effects of ozone on crops and (semi-)natural vegetation in Europe (1990-2006) in relation to AOT40- and flux-based risk maps. Global Change Biology 17:592-613.

Mills, G., Pleijel, H., Braun, S., Büker, P., Bermejo, V., Calvo, E., Danielsson, H., Emberson, L., González-Fernández, I., Grünhage, L., Harmens, H., Hayes, F., Karlsson, P.E. \& Simpson, D. (2011b). New stomatal flux-based critical levels for ozone effects on vegetation. Atmospheric Environment 45:5064-5068.

Monteith, J.L. (1965). Evaporation and Environment. Symposia of the Society for Experimental Biology 19:205-234

Musselman, R.C., Lefohn, A.S., Massman, W.J. \& Heath, R.L. (2006). A critical review and analysis of the use of exposure- and flux-based ozone indices for predicting vegetation effects. Atmospheric Environment 40:1869-1888.

Oksanen, E. \& Holopainen, T. (2001). Response of two birch (Betula pendula Roth) clones to different ozone profiles with similar AOT40 exposure. Atmospheric Environment 35, 52455254 .

Olsson, C. (2014). Tree phenology modelling in the boreal and temperate climate zones : Timing of spring and autumn events. PhD Thesis. Department of Physical Geography and Ecosystem Science, Lund University.

Paoletti, E., De Marco, A., Beddows, D., Harrison, R. \& Manning, W. (2014). Ozone levels in European and USA cities are increasing more than at rural sites, while peak values are decreasing. Environmental Pollution 192:295-299.

Parrish, D.D., Law, K.S., Staehelin, J., Derwent, R., Cooper, O.R., Tanimoto, H., VolzThomas, A., Gilge, S., Scheel, H.E., Steinbacher, M. \& Chan, E. (2012). Long-term changes in lower tropospheric baseline ozone concentrations at northern mid-latitudes. Atmospheric Chemistry and Physics 12:11485-11504. 

Thomas, A., Glige, S., Scheel, H.E., Steinbacher, M. \& Chan, E. (2013). Lower tropospheric ozone at northern midlatitudes: Changing seasonal cycle. Geophysical Research Letters

Peñuelas, J., Filella, I. \& Comas, P. (2002). Changed plant and animal life cycles from 1952 to 2000 in the Mediterranean region. Global Change Biology 8:531-544.

Pleijel, H., Danielsson, H., Gelang, J., Sild, E. \& Sellden, G. (1998). Growth stage dependence of the grain yield response to ozone in spring wheat (Triticum aestivum L.). Agriculture, Ecosystems and Environment 70:61-68.

Pleijel, H., Danielsson, H., Ojanpera, K., De Temmerman, L., Hogy, O., Badiani, M. \& Karlsson, P.E. (2004). Relationships between ozone exposure and yield loss in European wheat and potato - a comparison of concentration- and flux-based exposure indices. Atmospheric Environment 38:2259-2269.

Royal Society (2008). Ground-level ozone in the 21st century: future trends, impacts and policy implications. Science Policy Report 15/08. The Royal Society, London, UK.

Sicard, P., De Marco, A., Troussier, F., Renou, C., Vas, N. \& Paoletti, E. (2013). Decrease in surface ozone concentrations at Mediterranean remote sites and increase in the cities. Atmospheric Environment 79:705-715.

Soja, G., Barnes, J.D., Posch, M., Vandermeiren, K., Pleijel, H. \& Mills, G. (2000). Phenological weighting of ozone exposures in the calculation of critical levels for wheat, bean and plantain. Environmental Pollution 109:517-524.

Wagg, S., Mills, G., Hayes, F., Wilkinson, S., Cooper, D. \& Davies, W.J. (2012). Reduced soil water availability did not protect two competing grassland species from the negative effects of increasing background ozone. Environmental Pollution 165:91-99.

Wagg, S., Mills, G., Hayes, F., Wilkinson, S. \& Davies, W.J. (2013). Stomata are less responsive to environmental stimuli in high background ozone in Dactylis glomerata and Ranunculus acris. Environmental Pollution 175:82-91.

Wild, O., Fiore, A.M., Shindell, D.T., Doherty, R.M., Collins, W.J., Dentener, F.J., Schultz, M.G., Gong, S., MacKenzie, I.A., Zeng, G., Hess, P., Duncan, B.N., Bergmann, D.J., Szopa, S., Jonson, J.E., Keating, T.J. \& Zuber, A. (2012). Modelling future changes in surface ozone: a parameterized approach. Atmospheric Chemistry and Physics 12:2037-2054.

Wilson, R.C., Fleming, Z.L., Monks, P.S., Clain, G., Henne, S., Konovalov, I.B., Szopa, S. \& Menut, L. (2012). Have primary emission reduction measures reduced ozone across Europe? An analysis of European rural background ozone trends 1996-2005. Atmospheric Chemistry and Physics 12:437-454.

Wittig, V.E., Ainsworth, E.A., Naidu, S.L., Karnosky, D.F. \& Long, S.P. (2009). Quantifying the impact of current and future tropospheric ozone on tree biomass, growth, physiology and biochemistry: a quantitative meta-analysis. Global Change Biology 15, 396-424. 
787 Zhang, J., Schaub, M., Ferdinand, J., Skelly, J., Steiner, K. \& Savage, J. (2010). Leaf age 788 affects the responses of foliar injury and gas exchange to tropospheric ozone in Prunus 789 serotina seedlings. Environmental Pollution 158:2627-2634. 